\title{
Herbarium specimens as a source of DNA for AFLP fingerprinting of Phragmites (Poaceae): possibilities and limitations
}

\author{
C. Lambertini, J. Frydenberg, M. H. G. Gustafsson, H. Brix \\ Department of Biological Sciences, University of Aarhus, Aarhus C, Denmark
}

Received 4 April 2007; Accepted 5 November 2007; Published online 12 February 2008

(C) Springer-Verlag 2008

\begin{abstract}
Summary. Herbarium collections are a valuable source of genetic information. Even though the DNA obtained from the specimens is often highly fragmented and present in small quantities, it has been successfully used particularly for DNA sequencing and microsatellite analysis. The present study shows that the quality is often sufficient for use also for AFLPs. With this technique, a considerable number of DNA fragments with unknown sequence from the entire genome of the plant are amplified, often with the purpose of phylogeographic studies or analyses of interrelationships of closely related species. In order to avoid the effects of potential artefacts resulting from DNA degradation, such as "false polymorphisms", it is suggested that fresh samples should always be included for comparison, and that AFLP chromatograms based on herbarium specimens should be included in analyses only when they contain AFLP fragments monomorphic among the fresh samples, and when signal quality is comparable to that of fresh samples.
\end{abstract}

Keywords: Phragmites; common reed; herbarium specimens; DNA fragmentation; polymorphism; AFLP; fingerprinting

Herbarium collections represent a very important source of material for the plant sciences. Not only can herbarium specimens be used for various morphological investigations, but they are increasingly used also for molecular studies, as DNA is often preserved in the dried specimens. DNA extracted from herbarium material is, however, frequently highly fragmented. The extent of DNA degradation seems to be related to the conditions under which the specimen was dried and subsequently kept in the herbarium facilities. Factors that can negatively affect the DNA quality of herbarium specimens are heating in a microwave oven (used for drying and pest control; Hall 1981, Bacci et al. 1983, Hill 1983), fumigation (Metsger and Byers 1999) and disinfecting chemicals. According to Rogers and Bendich (1985) the DNA quality mostly depends on the condition of the fresh leaves, the developmental stage of the plant at the time of drying and on the method of drying, whereas the age of the specimen is less important. Several protocols for DNA extraction from herbarium samples have been described and most of them involve the CTAB method (Doyle and Doyle 1987, Doyle and Dickson 1987) with various modifications. To mention but a few examples, Wittzell (1999) isolated DNA with the CTAB method from herbarium specimens of

Correspondence: Carla Lambertini, Department of Biological Sciences, Plant Biology, University of Aarhus, Ole Worms Allé, Building 1135, 8000 Aarhus C, Denmark

e-mail: carla.lambertini@biology.au.dk 
Taraxacum Wigg. spp. (Asteraceae) and successfully used it for sequencing. Saltonstall (2002, 2003) extracted DNA with the CTAB method from herbarium material of Phragmites australis (Cav.) Trin. ex Steud. (Poaceae) for microsatellite studies and sequencing, after cleaning with $10 \%$ bleach to remove mounting glue, and treating the material with UV light for $5 \mathrm{~min}$ to remove surface contaminants. Drabkova et al. (2002), in a study of sequence variation in the family Juncaceae, chose the DNeasy Plant Kit (Qiagen), after trying seven different extraction and amplification protocols. Recent studies of non-angiosperm plants include that of De Castro and Menale (2004), who followed the protocol by Ristaino et al. (2001) to isolate DNA from species of Pinaceae for microsatellite studies, and that of Jankowiak et al. (2005) who used the DNeasy Plant Mini Kit (Qiagen) to obtain DNA sequences of bryophytes.

Amplified fragment length polymorphisms (AFLPs) is a DNA fingerprinting technique that detects genomic restriction fragments. One of the advantages is that it does not require prior sequence knowledge (Vos et al. 1995). This technique has mostly been used in population genetic studies, but has been successful also in a number of taxonomic studies in groups of closely related species (Lara-Cabrera and Spooner 2004, Muñoz et al. 2006, Bacon and Bailey 2006). A recent trend in phylogeographic (Schönswetter et al. 2007) and phylogenetic studies (Desprès et al. 2003, Semerikov et al. 2003, Van Ee et al. 2006) is the combination of DNA sequences with AFLP data, as the large number of "characters" (absence or presence of fragments) provided by AFLPs may significantly improve resolution where sequence data alone are insufficient.

High purity genomic DNA is required for AFLP to ensure complete digestion by the restriction endonucleases. DNA fragmentation, as seen in e.g. herbarium material, may result in an altered band pattern (Vos et al. 1995, Blears et al. 1998). Particularly problematic is the interpretation of absence of fragments, which may be due to degradation rather than genetic polymorphism. An additional, potential source of error is the use of ligase in the AFLP procedure, as this enzyme might ligate DNA fragments that do not belong together, thus creating recombinant AFLP bands.

The present work demonstrates the utility of herbarium material as a source of DNA for use in AFLP studies, and points to some important considerations in the evaluation and analysis of the resulting chromatograms. The investigation is part of a widely sampled study of the genetic variation within the genus Phragmites Adans. (Poaceae) based on a combination of fresh samples and herbarium specimens. The first part of this investigation, a phylogeographic study based on AFLPs alone, has recently been published (Lambertini et al. 2006).

\section{Materials and methods}

DNA extraction. DNA was extracted from 204 fresh specimens (Lambertini et al. 2006) and 29 herbarium specimens (Table 1) of Phragmites. Most of the specimens belong to the widespread $P$. australis, but four other species in this small and taxonomically difficult genus are also represented. Extraction was performed using the Qiagen DNeasy Plant Mini Kit. The protocol provided by Qiagen was followed for fresh material. For herbarium material (leaves and inflorescences), the protocol was modified in that $20 \mathrm{mg}$ of dry plant tissue was ground in a mortar with quartz sand and about $3 \mathrm{ml}$ liquid nitrogen into a very fine powder. A total of $500 \mu \mathrm{l}$ of preheated $\left(60^{\circ} \mathrm{C}\right)$ AP1 buffer (Qiagen) were added, and grinding was continued until a completely homogeneous mixture was obtained. After grinding, $4 \mu \mathrm{l}$ RNAase $(100 \mathrm{mg} /$ $\mathrm{ml})$ and $4 \mu \mathrm{l}$ Proteinase K $(19.45 \mathrm{mg} / \mathrm{ml})$ were added. The mixture was then transferred to an eppendorf tube and incubated at $60^{\circ} \mathrm{C}$ for $1 \mathrm{~h}$. A total of $150 \mu \mathrm{AP} 2$ buffer (Qiagen) were added and the Qiagen extraction protocol was then followed to the final step, in which the DNA was eluted with $50 \mu 1$ preheated $\left(60^{\circ} \mathrm{C}\right) \mathrm{AE}$ buffer. The DNA was visualized on a $0.8 \%$ agarose gel, run for $1 \mathrm{~h}$ at $120 \mathrm{~V}$ in an electrophoresis chamber and stained with ethidium bromide.

PCR amplification. The AFLP protocol for herbarium specimens and for fresh material is described by Lambertini et al. (2006). The primer combinations E-ACTcy (5'-AGACTGCGTACCAAT TCACT- $\left.3^{\prime}\right)+$ M-CTT (5'-GATGAGTCCTGAGT AACTT-3'), E-CAGcy (5'-GACTGCGTACCAATT CCAG- $\left.3^{\prime}\right)+$ M-ATG (5'-GATGAGTCCTGAGTA ACAG- $\left.3^{\prime}\right)$ and E-CGTcy (5'-GACTGCGTACCAAT 


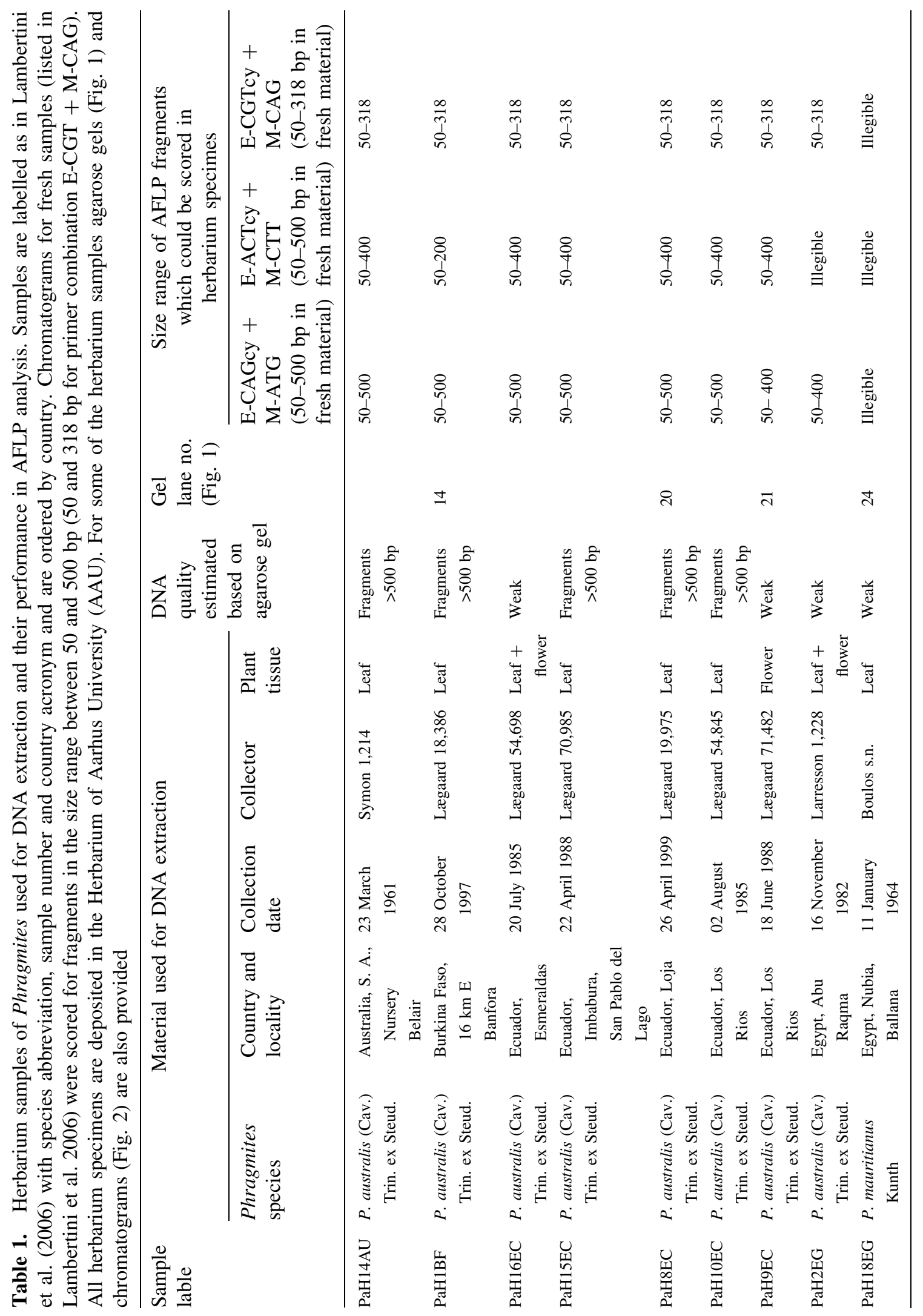




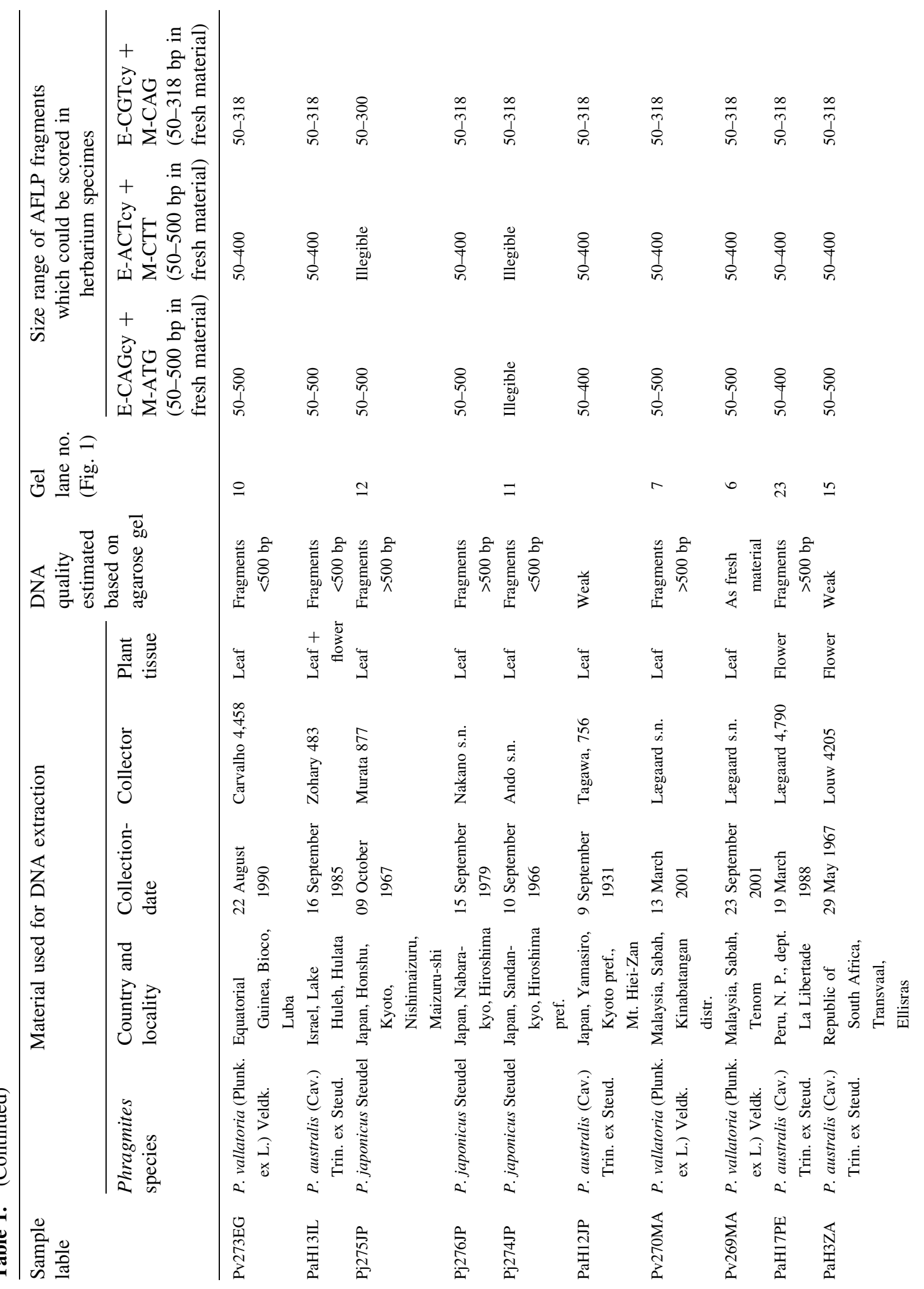




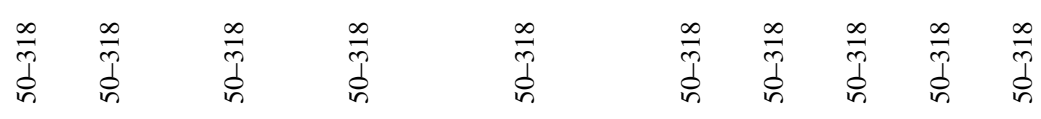

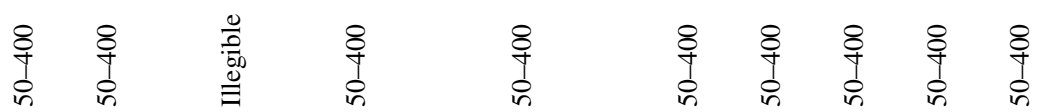

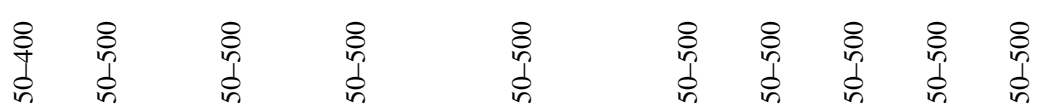

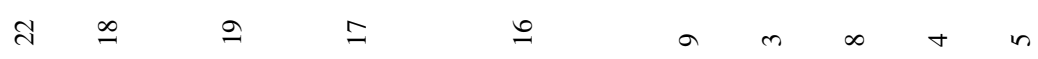

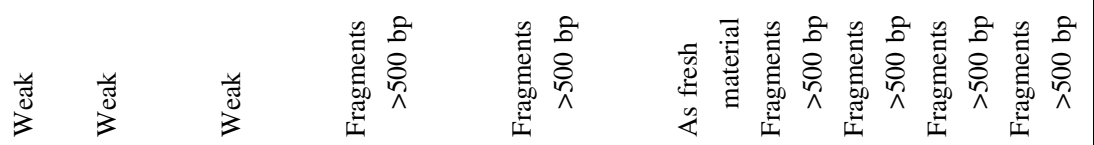

岕

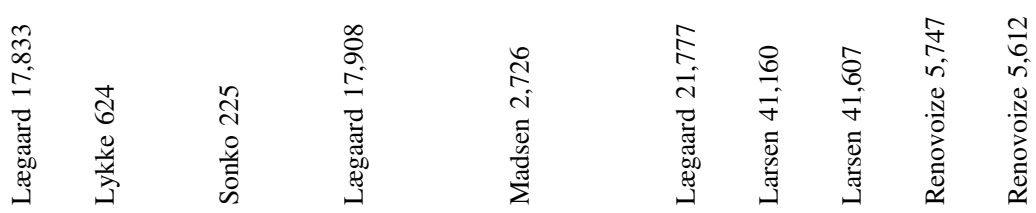

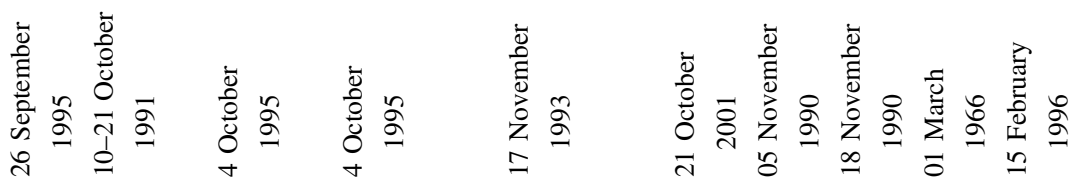

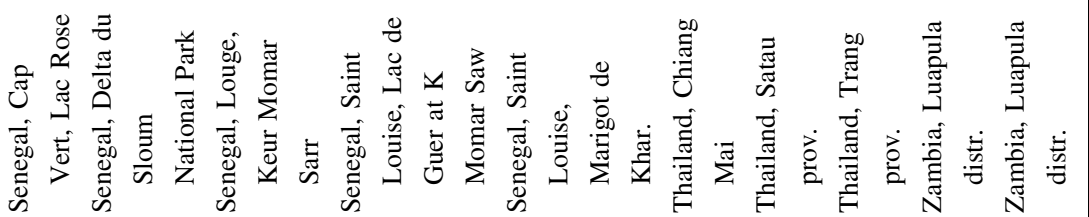

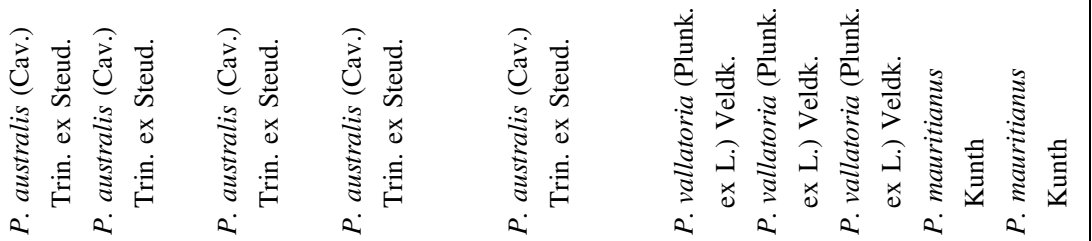

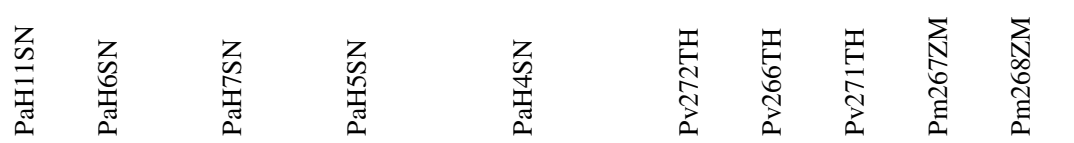


TCCGT-3') + M-CAG (5'-GATGAGTCCTGAGTA ACAG-3') were used.

AFLP scoring. AFLP fragments were scored manually based on chromatograms visualized by the ALFwin Fragment Analyser Software Package (Amersham Biosciences). Only chromatograms that contained all monomorphic fragments present in fresh material while not showing interruption and/or distortion of the signal were scored for presence or absence of polymorphic fragments in the herbarium specimens.

Data analysis. The binary matrix (available from the corresponding author) of AFLP characters including both fresh and herbarium material was analysed using parsimony analysis and neighbourjoining by the program PAUP*4.0b10 (Phylogenetic analysis using parsimony; Swofford 1998). The results are presented in Lambertini et al. (2006).

\section{Results}

The quality of extracted DNA varies among the specimens, and appears to be independent of sample collection date and type of tissue used (leaf, flowers or both; Table 1). Judging from the appearance of the total DNA on the agarose gel (Fig. 1), two herbarium specimens yielded DNA of a quality similar to that of the fresh specimens (samples Pv269MA and Pv272TH, gel lanes 6 and 9), but several samples showed signs of degradation. In most of the cases degraded DNA contained fragments longer than $500 \mathrm{bp}$, but in one case (sample Pj274JP, gel lane 11) DNA fragments were clearly shorter than $500 \mathrm{bp}$. Samples PaH6SN and PaH7SN (gel lanes 18 and 19) contained a very low amount of DNA. Even though DNA quality in the herbarium specimens was often poor, most of them yielded AFLP patterns. The length of the readable part of the chromatograms varied between samples (Table 1). The herbarium samples showed a variation range similar to that of the fresh samples, but some of them showed interruption

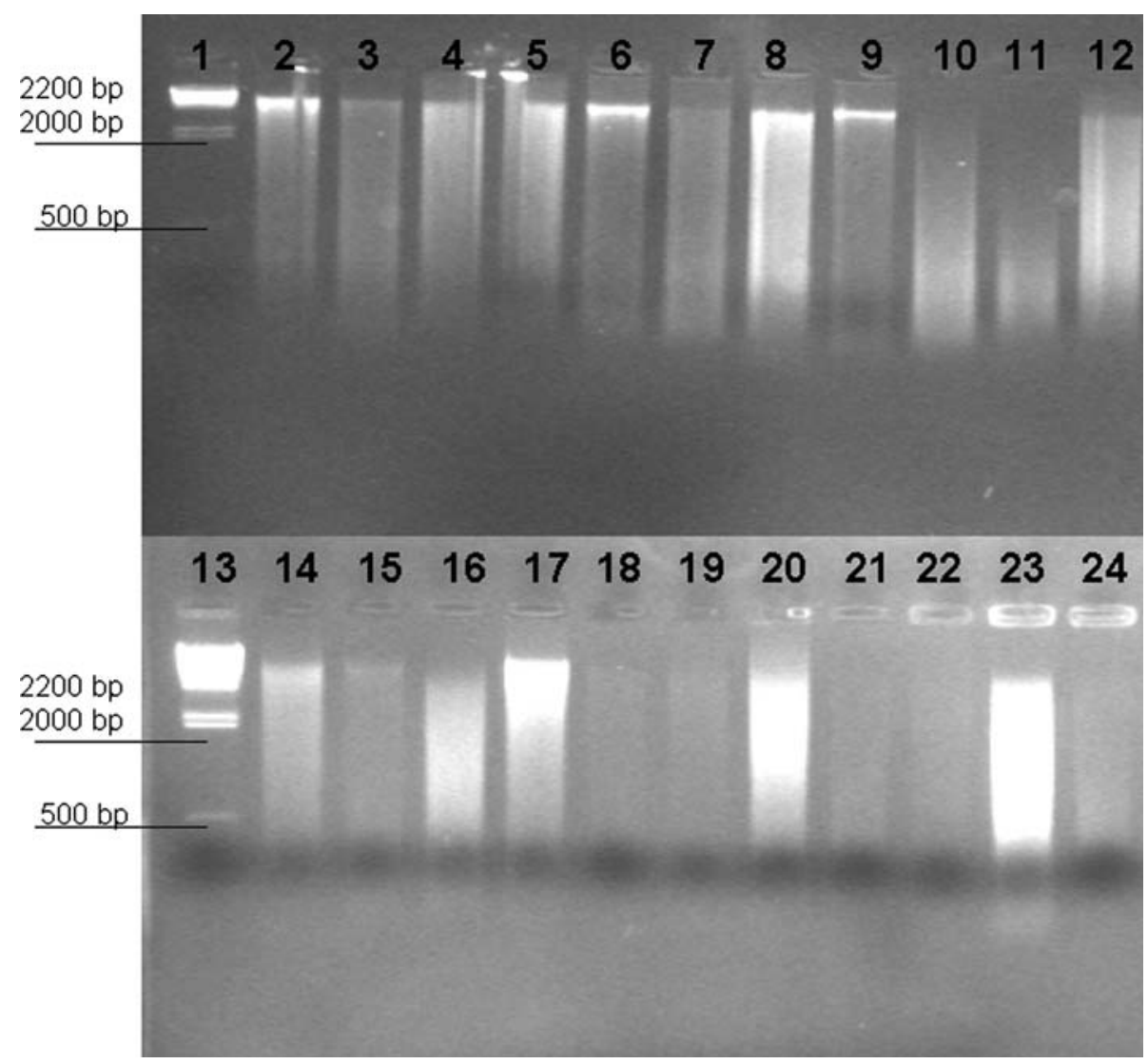

Fig. 1. Agarose gel of DNA extracted from fresh (lane 2) and herbarium (lanes 3-24) specimens of Phragmites. Lanes 1 and 13 are Lambda DNA/HindIII marker 


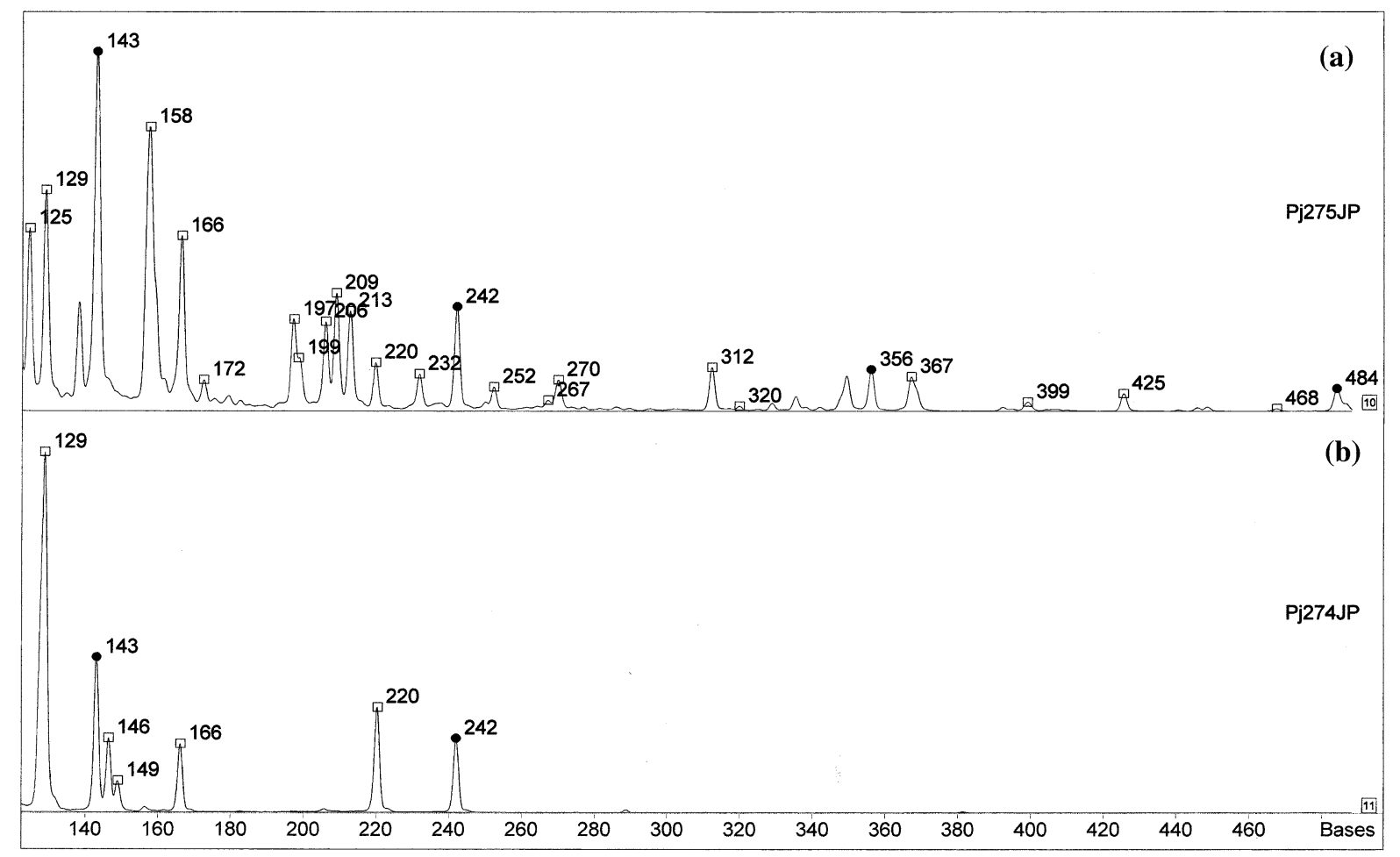

Fig. 2. AFLP fragments amplified by primers E-CAG + M-ATG, from 125 to 484 bp. a Herbarium specimen Pj275JP and $\mathbf{b}$ herbarium specimen PJ247JP. Specimen Pj275JP shows signs of DNA degradation but contains DNA fragments longer than $500 \mathrm{bp}$ (gel lane 12, Fig. 1). Even though the intensity of the chromatogram signal decreases for the longest AFLP fragments, the chromatogram is readable up to $500 \mathrm{bp}$. All monomorphic peaks present in fresh material samples are present also in this sample $(143,242,356,484)$. Herbarium specimen Pj274JP b shows signs of DNA degradation and contains mainly DNA fragments shorter than 500 bp (gel lane 11, Fig. 1). The chromatogram signal is interrupted between 166 and $220 \mathrm{bp}$ and between 242 and $500 \mathrm{bp}$, and is considered illegible

and/or distorted parts in the chromatogram signal (Fig. 2), especially for the longest AFLP fragments, between 400 and $500 \mathrm{bp}$.

Considering the risk that absence of a certain fragment in the herbarium samples might be due to DNA degradation, the presence of fragments monomorphic in the fresh subset was checked in the herbarium subset. Herbarium samples were scored and included in the analysis only if monomorphic peaks present in chromatograms from fresh material were present also in the herbarium samples. Herbarium samples that failed this test were excluded. All in all, 128 fragments (obtained by three primer combinations) met this criteria and were scored in the herbarium specimens.
Considering the whole data set, five herbarium specimens out of 29, yielded chromatograms too poor to be scored, being distorted and/or containing parts with very weak signal. One of the primer combinations (E-ACTcy + M-CTT) was unsuccessful for four of the herbarium samples, while the fifth (sample PmH18EG) yielded poor chromatograms with all primers used. Four of the unsuccessful samples contained low amounts of DNA and/or signs of degradation (mostly short fragments).

\section{Discussion}

AFLPs are an important source of information for analysis of biodiversity patterns and processes, 
particularly at levels ranging from population to species. The high success rate found here shows that it is possible to use herbarium material in AFLP studies. The use of herbarium specimens allows the sampling of taxa and geographical areas that may be otherwise inaccessible because of practical and/or economical reasons. There are, however, important limitations to take into consideration. In our study, a large and geographically widely sampled dataset, obtained from fresh plant tissue, was a prerequisite for the use of herbarium material. Herbarium specimens were included to improve the geographical representation of samples. In order to evaluate if DNA extracted from herbarium specimens could be used in AFLP, and to minimize possible effects of DNA degradation, such as false negatives, we checked for presence of fragments that were monomorphic in the fresh subset. Moreover, we used only parts of the chromatograms that were comparable in quality with those obtained from fresh specimens, i.e. not distorted and/or with interrupted signal.

Based on this experience, our advice for the AFLP fingerprinting of herbarium material is to use short AFLP fragments (up to $300 \mathrm{bp}$, depending on the quality/quantity of DNA and chromatograms). To compensate for using only part of the chromatogram, it may be necessary to increase the number of primer combinations in order to obtain a sufficient number of polymorphic fragments (characters) to obtain phylogenetic resolution. Visualization of total DNA on agarose gels is often helpful, as it shows quality and quantity of DNA and indicates where DNA degradation might be a problem, i.e. when long fragments (>500 bp) are largely missing. It should be stressed, however, that even samples for which DNA appearance on the agarose gel showed small amount and/or low quality may in some cases work well for AFLP. Thus, exclusion of samples based on agarose gel appearance alone is unwarranted. The combination with samples based on fresh material is also extremely important as a reference and in order not to misinterpret "herbarium polymorphisms".

\section{References}

Bacci M, Checcucci G, Palandri MR (1983) A rapid DNA isolation procedure for small quantities of fresh leaf tissue. Phytochem Bull 19: 11-15

Bacon CD, Bailey CD (2006) Taxonomy and conservation: a case study from Chamaedorea alternans. Ann Bot 98: 755-763

Blears MJ, De Grandis SA, Lee H, Trevors JT (1998) Amplified fragment length polymorphism (AFLP): a review of the procedure and its applications. J Ind Microbiol Biotechnol 21: 99-114

De Castro O, Menale B (2004) PCR amplification of Michele Tenore's historical specimens and facility to utilize an alternative approach to resolve taxonomic problems. Taxon 53: 147-151

Desprès L, Gielly L, Redoutet B, Taberlet P (2003) Using AFLP to resolve phylogenetic relationships in a morphologically diversified plant species complex when nuclear and chloroplast sequences fail to reveal variability. Molec Phylogenet Evol 27: $185-196$

Doyle JJ, Dickson EE (1987) Preservation of plant samples for DNA restriction endonuclease analysis. Taxon 36: 715-722

Doyle JJ, Doyle JL (1987) A rapid DNA isolation procedure for small quantities of fresh leaf tissue. Phytochem Bull 19: 11-15

Drabkova L, Kirschner J, Vleck C (2002) Comparison of seven DNA extraction and amplification protocols in historical herbarium specimens of Juncaceae. Pl Molec Biol Rep 20: 161-175

Hall DV (1981) Microwave: a method to control herbarium insects. Taxon 30: 818-819

Hill SR (1983) Microwave and herbarium specimens: potential dangers. Taxon 32: 614-615

Jankowiak K, Buczkowska K, SzweykowskaKulinska Z (2005) Successful extraction of DNA from 100-year-old herbarium specimens of the liverwort Bazzania trilobata. Taxon 54: 335336

Lambertini C, Gustafsson MHG, Frydenberg J, Lissner J, Speranza M, Brix H (2006) A Phylogeographic study of the cosmopolitan genus Phragmites (Poaceae) based on AFLPs. Pl Syst Evol 258: 161-182

Lara-Cabrera SI, Spooner DM (2004) Taxonomy of North and Central American diploid wild potato (Solanum sect. Petota) species: AFLP data. Pl Syst Evol 248: 129-142

Metsger DA, Byers SC (1999) Managing the modern herbarium, an interdisciplinary approach. Society 
of the Preservation of Natural History Collections, Washington DC, 384p

Muñoz LC, Duque MC, Debouck GD, Blair MW (2006) Taxonomy of tepary bean and wild relatives as determined by amplified fragment length polymorphism (AFLP) markers. Crop Sci 46: 1744-1754

Ristaino JB, Groves CT, Parra GR (2001) PCR amplification of the Irish potato famine pathogen from historic specimens. Nature 411: 695-697

Rogers SO, Bendich AJ (1985) Extraction of DNA from milligram amounts of fresh, herbarium and mummified plant tissue. Pl Molec Biol 5: 69-76

Saltonstall K (2002) Cryptic invasion by a non-native genotype of the common reed, Phragmites australis, into North America. Proc Natl Acad Sci USA 99: 2445-2449

Saltonstall K (2003) Microsatellite variation within and among North American lineages of Phragmites australis. Molec Ecol 12: 1689-1702

Schönswetter P, Suda J, Popp M, Weiss-Schneeweiss H, Brochmann C (2007) Circumpolar phylogeography of Juncus biglumis (Juncaceae) inferred from AFLP fingerprints, cpDNA sequences, nuclear DNA content and chromosome numbers. Molec Phylogenet Evol 42: 92-103

Semerikov VL, Zhang H, Sun M, Lascoux M (2003) Conflicting phylogenies of Larix (Pinaceae) based on cytoplasmatic and nuclear DNA. Molec Phylogenet Evol 27: 173-184

Swofford DL (1998) PAUP. Phylogenetic analysis using parsimony (and other methods). Version 4, Sinauer Associates, Sunderland

Van Ee BW, Jelinski N, Berry PE, Hipps AL (2006) Phylogeny and biogeography of Croton alabamensis (Euphorbiaceae), a rare shrub from Texas and Alabama, using DNA sequence and AFLP data. Molec Ecol 15: 2735-2751

Vos P, Hogers R, Bleeker M, Reijans M, Van De Lee T, Hornes M, Frijters A, Pot J, Peleman J, Kuiper M, Zabeau M (1995) AFLP: a new technique for DNA fingerprinting. Nucleic Acids Res 23: 44074414

Wittzell H (1999) Chloroplast DNA variation and reticulate evolution in sexual and apomitic sections of dandelions. Molec Ecol 8: 2023-2035 